University of Pennsylvania Carey Law School

Penn Carey Law: Legal Scholarship Repository

Faculty Scholarship at Penn Carey Law

$1-2020$

\title{
The Uncertain Stewardship Potential of Index Funds
}

Jill E. Fisch

University of Pennsylvania Carey Law School

Follow this and additional works at: https://scholarship.law.upenn.edu/faculty_scholarship

Part of the Business Law, Public Responsibility, and Ethics Commons, Business Organizations Law Commons, Economic Policy Commons, Law and Economics Commons, Law and Society Commons, Policy Design, Analysis, and Evaluation Commons, and the Social Policy Commons

\section{Repository Citation}

Fisch, Jill E., "The Uncertain Stewardship Potential of Index Funds" (2020). Faculty Scholarship at Penn Carey Law. 2139.

https://scholarship.law.upenn.edu/faculty_scholarship/2139

This Book Chapter is brought to you for free and open access by Penn Carey Law: Legal Scholarship Repository. It has been accepted for inclusion in Faculty Scholarship at Penn Carey Law by an authorized administrator of Penn Carey Law: Legal Scholarship Repository. For more information, please contact PennlawIR@law.upenn.edu. 


\title{
THE UNCERTAIN STEWARDSHIP POTENTIAL OF INDEX FUNDS
}

\author{
JILL FISCH *
}

\begin{abstract}
Regulators and commentators around the world are increasingly demanding that institutional investors engage in stewardship with respect to their portfolio companies. Further, the demand for stewardship has broadened from an expectation that investors engage to reduce agency costs and promote economic value to a call for investors to demand that companies serve a broader range of societal interests and objectives. This chapter considers calls for stewardship in the context of the U.S. capital markets specifically as applied to index funds. It argues that, irrespective of the merits of institutional stewardship generally, the structure of index funds and the business environment in which they operate limits their ability to engage in effective stewardship. Although index fund sponsors have had a powerful influence on their portfolio companies, well-intentioned calls for them to play a more significant role and, in particular, claims that they should incorporate non-economic objectives more broadly into their engagement strategy, are in tension with the valuable role that index funds serve in the U.S. markets by providing a low-cost diversified investment option for an increasing segment of ordinary citizens. The chapter concludes by considering the possibility of using pass-through voting to enhance the stewardship potential of index funds.
\end{abstract}

\section{INTRODUCTION}

Policymakers around the world are demanding that large institutional investors act as responsible stewards of their portfolio companies. ${ }^{1}$ The principal rationale behind the stewardship movement is that engaged institutional investors offer the potential to reduce managerial agency costs. ${ }^{2}$

* Jill Fisch is the Saul A. Fox Distinguished Professor of Business Law and CoDirector of the Institute for Law \& Economics at the University of Pennsylvania School of Law.

${ }^{1}$ See, e.g., Jennifer G. Hill, 'Good Activist/Bad Activist: The Rise of International Stewardship Codes' (2018) 41 Seattle U. L. Rev. 497, 506-513 (describing global attention to stewardship following the UK's creation of the world's first stewardship code).

${ }^{2}$ See, e.g., Tim Bowley \& Jennifer G. Hill, 'Collective Activism and Shareholder Stewardship: The Australian Experience' (this volume, draft at 1-2) (observing that UK stewardship code was adopted to address lack of shareholder participation in 
Some commentators have also argued that institutional investors should go further and address broader societal concerns such as the interests of nonshareholder stakeholders and ESG considerations through their voting power, an pesrspective that has been formalized in the 2020 version of the U.K Stewardship Code. ${ }^{3}$

The challenge for the stewardship movement is that it treats institutional investors - primary large asset managers - as shareholders rather than intermediaries. Both the structure and the business model of mutual funds limit their potential stewardship role in ways that stewardship advocates do not seem to appreciate fully. Because of this, although the increasingly-concentrated institutional ownership of public corporations has substantially mitigated the agency problems identified by Berle and Means, ${ }^{4}$ institutional intermediaries cannot replicate the actions and incentives of true blockholders. ${ }^{5}$ As a result, commentators' expectations about the potential value of investor stewardship may be unrealistic.

As this chapter explains, the asset management industry, which dominates institutional shareownership in the United States, faces two critical constraints. First, its business model - and, in particular, the increasing flow of assets into low-cost passively-managed investment vehicles such as index funds and ETFs (collectively "index funds") -- is not consistent with the kind of analysis necessary to provide substantial firm-specific oversight of corporate officers and directors of their portfolio companies on a cost-effective basis. Second, as the scope of the stewardship movement becomes more capacious, it calls for investors to make operational and governance choices, but the relationship between asset managers and fund beneficiaries provides a tenuous basis for making those choices.

Although commentators have called for mutual funds to devote greater resources to stewardship through more frequent engagement as well as the

corporate governance and based on the view that greater engagement would operate "as a check on centralised managerial power").

${ }^{3}$ See Financial Reporting Council, The UK Stewardship Code 2020 (2020) https://www.frc.org.uk/getattachment/5aae591d-d9d3-4cf4-814ad14e156a1d87/Stewardship-Code Final2.pdf, at 8, Principle 1 (advocating "stewardship that creates longterm value for clients and beneficiaries leading to sustainable benefits for the economy, the environment and society").

${ }^{4}$ See Adolf A. Berle \& Gardiner C. Means, The Modern Corporation and Private Property (1 ${ }^{\text {st }}$ ed. Macmillan 1932).

${ }^{5}$ See Alex Edmans \& Clifford G. Holderness, 'Blockholders: A Survey of Theory and Evidence' (2017) https://ssrn.com/abstract=2820976 (identifying challenges in defining what level of ownership characterizes a blockholder and presenting data on large-block ownership in the United States). 
increased use of shareholder proposals and even litigation, ${ }^{6}$ they have not reflected on the tension between the costs of that stewardship and the benefits that today's mutual funds offer their beneficiaries by providing diversified investment vehicles at unprecedently low fees. ${ }^{7}$ Nor do they explain why it would be cost-effective for those who offer a low-cost financial product that does not require firm-specific investment analysis to invest resources to develop operational or governance expertise. Indeed, even with respect to the broadbased governance initiatives in which institutions have been actively engaged, there are questions about the extent to which the policies they advocate are consistent with enhancing firm value.

To address the concern that institutional investors may be poorly positioned to incorporate the economic and non-economic preferences of their beneficiaries into their stewardship or lack the authority to make those choices on behalf of those beneficiaries, several recent proposals have called for asset managers to determine those preferences by consulting with their beneficiaries. ${ }^{8}$ For asset managers such as mutual funds, where direct consultation may be impractical, some commentators have called for pass-through voting. ${ }^{9}$ The limitations of these proposals highlight the difficulty inherent in developing a workable stewardship policy for an institutional intermediary, particularly a policy that incorporates non-economic considerations.

The chapter proceeds as follows. Part I describes U.S. developments in response to the global stewardship movement and, in particular efforts to encourage institutional investors to engage with their portfolio companies as "good corporate stewards." Part II focuses on the specific case of the index fund,

${ }^{6}$ See, e.g., Lucian Bebchuk \& Scott Hirst, 'Index Funds and the Future of Corporate Governance: Theory, Evidence, and Policy' (2019) _ Colum. L. Rev.

(forthcoming); Sean Griffith \& Dorothy Lund, 'Toward a Mission Statement for $\bar{M}$ utual Funds in Shareholder Litigation' (2019) _ U. Chi. L. Rev. (forthcoming).

${ }^{7}$ Research demonstrates that "the growth of explicitly indexed funds worldwide enhances competition in the asset management industry." Martijn Cremers, Miguel A. Ferreira, Pedro Matos \& Laura Starks 'Indexing and Active Fund Management: International Evidence' (forthcoming 2020) _ J. Fin. Econ _, https://www.darden.virginia.edu/sites/default/files/inline-files/indexing-world2015-publication.pdf.

${ }^{8}$ See EU High-Level Group on Sustainable Finance, Financing a Sustainable European Economy (2018) https://ec.europa.eu/info/sites/info/files/180131sustainable-finance-final-report en.pdf 74 ("Pension funds should consult beneficiaries on their sustainability preferences and build those into their investment strategy.").

${ }^{9}$ Caleb N. Griffin, 'We Three Kings: Disintermediating Voting at the Index Fund Giants' (2019) Md. L. Rev., https://papers.ssrn.com/sol3/papers.cfm?abstract_id=3365222. 
offering a brief explanation of its structure and business model. Part III explains why this business model is inconsistent with aggressive firm-specific stewardship - specifically a stewardship model that entails firm-specific monitoring of operational decisions. Part IV considers the challenge presented by demands that index funds incorporate ESG and sustainability considerations into their stewardship efforts. Finally Part V explores the distinctive nature of index fund beneficiaries -- the individuals who invest in index funds -- and the implications for proposals to empower those beneficiaries.

A cautionary note is in order. This chapter focuses on the specific role of index funds and does not consider the extent to which the limitations identified herein are applicable to other types of institutional investors such as actively-managed mutual funds, hedge funds, banks, public pension funds and sovereign wealth funds. Notably, the observations in this chapter are decidedly U.S.-centric and have more limited applicability to jurisdictions in which other types of instituitonal investors dominate. The core observation of this chapter, however, is that institutional context matters. Thus in considering the potential value of investor stewardship, policymakers would do well to reflect on the business model and structural details of the institutions that they seek to engage.

\section{INVESTOR STEWARDSHIP - THE U.S. PERSPECTIVE}

As reflected in the 2010 version of the UK Stewardship Code, investor stewardship was initially intended to encourage institutional investors to respond to managerial agency problems - primarily excessive risk-taking and shorttermism. ${ }^{10}$ In the United States, stewardship reflected the potential ability of the reconcentration of ownership to address the classic Berle and Means problem of unchecked managerial power in the U.S. publicly-traded corporation. ${ }^{11}$ Berle and Means wrote at a time when the stock of U.S. public companies was held primarily by dispersed retail investors who lacked the incentive and expertise to monitor management and limit agency costs. The rise of the institutional investor offered the possibility of reducing these agency costs.

Today institutional investors own approximately $70 \%$ of the stock of large U.S. public companies, and these holdings are concentrated in a handful of

${ }^{10}$ Financial Reporting Council, UK Stewardship Code 2010, available at: http://www.frc.org.uk/Our-Work/Codes-Standards/Corporate-governance/UKStewardship-Code.aspx.

${ }^{11}$ See, e.g., Mariana Pargendler, 'The Corporate Governance Obsession,' (2016)

42 Iowa J. Corp. L. 359, 370-71 (describing Berke \& Means' identification of corporate governance problems as based, in part, on "unchecked managerial power"). 
the largest institutions. ${ }^{12}$ In the United States, the largest institutional investors are asset management firms such as BlackRock, Vanguard, StateStreet, Charles Schwab and Fidelity, each of which manages trillions of dollars in assets. Collecively BlackRock, Vanguard and StateStreet (commonly known as the "Big Three") 13 "are together the largest owner in 88 percent of the S\&P 500 [and are] the largest shareholder in 40 percent of listed firms in the U.S." 14

Despite the growing size of their holdings, for many years institutional investors in the United States were not actively engaged in corporate governance - they often did not vote their shares, they ignored the governance of their portfolio companies ${ }^{15}$ and they did not even seek to collect the damages available to them through shareholder litigation. ${ }^{16}$ Over the past thirty years, however, that situation has changed substantially. Institutional investors have become increasingly active through a range of public and private engagement efforts, and corporations have responded to these efforts with governance structures that provide greater transparency and accountability. ${ }^{17}$

Even with the increasing involvement of institutional investors in corporate governance, the 2008 financial crisis caused a number of

${ }^{12}$ Ben W. Heineman, Jr. \& Stephen Davis, 'Are Institutional Investors Part of the Problem or Part of the Solution?,' (2011) https://web.law.columbia.edu/sites/default/files/microsites/millsteincenter/80235 CED WEB.pdf, at 4.

${ }^{13}$ See, e.g., Jan Fichtner, Eelke M. Heemskerk \& Javier Garcia-Bernardo, 'Hidden Power of the Big Three? Passive Index Funds, Re-concentration of Corporate Ownership, and New Financial Risk' (2017) 19 Bus. \& Pol. 298, 298, 304 (explaining that BlackRock, Vanguard and State Street dominate the passive fund industry and terming them the "big three").

${ }^{14}$ Bob Eccles, 'Concentration In The Asset Management Industry: Implications For Corporate Engagement' Forbes (17 April 2019), https://www.forbes.com/sites/bobeccles/2019/04/17/concentration-in-the-assetmanagement-industry-implications-for-corporate-engagement/\#bf13c44402f5

15 See, e.g., Paul Rose, 'The Corporate Governance Industry,' (2007) 32 J. Corp. L. 887, 897 ("Unless an institutional investor believes that it can conduct research for less, or that more expensive but discerning research will enable it to obtain better returns (after subtracting its own research costs), the investor may be better off outsourcing its corporate governance research.").

${ }^{16}$ James Cox \& Randall Thomas, 'Leaving Money on the Table: Do Institutional Investors Fail to File Claims in Securities Class Actions?' (2002) 80 Wash. U L Q 855.

${ }^{17}$ See, e.g., Jill E. Fisch, Assaf Hamdani \& Steven Davidoff, 'The New Titans of Wall Street: A Theoretical Framework for Passive Investors' (2020) U. Pa. L. Rev. (forthcoming) (detailing growth of engagement by institutional investors in corporate governance). 
commentators to believe that investors were falling short. ${ }^{18}$ In the UK, this led the UK Financial Reporting Council to adopt the 2010 UK Stewardship Code, which is often described as "the world's first stewardship code"19 The UK stewardship code, which has subsequently been refined, ${ }^{20}$ is the model for stewardship codes around the world. ${ }^{21}$ Commentators and regulators in many jurisdictions have embraced the idea that institutional investors have an obligation to engage in active stewardship of their portfolio companies and have identified a variety of potential benefits from stewardship. ${ }^{22}$ In April 2017, the European Union imposed a requirement, as part of its revised Shareholder Rights Directive, that institutional investors publicly disclose how they integrate shareholder engagement into their investment strategies or explain why they do not do so. ${ }^{23}$

U.S. regulators have not adopted a formal requirement of investor stewardship. Certain components of what might be deemed a stewardship function are implicit, however, in other legal requirements that apply to institutional investors. For example, both the courts and Congress have recognized that investment advisers owe fiduciary duties to the mutual funds they manage. ${ }^{24}$ In 2003, the Securities and Exchange Commission adopted rules requiring mutual funds to develop voting policies and procedures as well as how

${ }^{18}$ Arad Reisberg, The UK Stewardship Code: On the Road to Nowhere?' (2015) 15 J. Corp. L. Stud. 217, 219

${ }^{19}$ Lee Roach, 'The UK Stewardship Code' (2011) 11 J. Corp. L. Stud. 463.

${ }^{20}$ Financial Reporting Council, UK Stewardship Code, http://www.frc.org.uk/Our-Work/Publications/Corporate-Governance/UKStewardship-Code-September2012.aspx; FRC, 2020 Stewardship Code, supra.

${ }^{21}$ See Simon Wong, 'Is Institutional Investor Stewardship Still Elusive?' (2015)

Harv Law School Forum on Corp Gov \& Fin. Reg.,

https://corpgov.law.harvard.edu/2015/09/24/is-institutional-investor-stewardshipstill-elusive-2/ ("Five years after the launch of the landmark UK Stewardship Code, counterparts can be found on four continents").

${ }^{22}$ See Ernst \& Young, 'Q\&A on Stewardship Codes' (2017) https://www.ey.com/Publication/vwLUAssets/ey-stewardship-codes-august2017/\$FILE/ey-stewardship-codes-august-2017.pdf (describing the proliferation of stewardship codes around the world and explaining that they "typically offer guidance to investors on how they should exercise their ownership and governance responsibilities, and how they should interact with the companies in which they invest").

${ }^{23}$ Press Release, Eur. Comm., 'Shareholders' rights directive Q\&A' (13 March, 2017), https://ec.europa.eu/commission/presscorner/detail/en/MEMO_17_592

${ }^{24}$ Howard Schiffman, 'The Relationship Between the Investment Advisor and the Mutual Fund: Too Close for Comfort' (1976) 45 Ford L. Rev. 183, 183-84. 
they voted their proxies at their portfolio companies. ${ }^{25}$ At the same time, the SEC adopted rules under the Investment Advisers Act requiring investment adviser to adopt policies to ensure that the funds' voting power is exercised in the "best interest" of the fund. ${ }^{26}$

Recently, a group of leading institutional investors in the United States, went further, forming the Investor Stewardship Group (ISG), a private group of institutional investors formed in 2017 for the purpose of establishing "the Framework for U.S. Stewardship and Governance" 27 According to its website, the ISG consists of 41 signatories and 24 additional "endorsers." 28 The group includes some of the world's largest asset managers and pension funds such as BlackRock, CalPERS, Goldman Sachs Asset Management, Hermes and UBS. ${ }^{29}$

The ISG framework, a framwork that that Jennifer Hill calls an "investorled" stewardship code, ${ }^{30}$ sets out both "common expectations" regarding corporate governance practices of portfolio companies and "a set of fundamental stewardship responsibilities for institutional investors" ${ }^{31}$ In celebrating the one year anniversary of its release of the framework, the ISG touted its "remarkable success." ${ }^{32}$ Yet whether the ISG framework will stimulate a meaningful change in the stewardship function of asset managers in the United States remains to be seen. Notably, to date, although the signatories include several major asset managers, the number of signatories is limited. A substantial component of the framework focuses on the governance of portfolio companies as opposed to the

${ }^{25}$ Disclosure of Proxy Voting Policies and Proxy Voting Records by Registered Management Investment Companies, Investment Company Act Release No. 25922, 68 Fed. Reg. 6564, 6566-67 (7 Feb. 2003) (codified at 17 C.F.R. pts. 239, 249, 270, 274)

${ }^{26}$ Proxy Voting by Investment Advisers, Investment Advisers Act Release No. 2106 (31 Jan. 2003), 68 FR 6585 (7 Feb. 2003).

${ }^{27}$ Investor Stewardship Group 'About the Investor Stewardship Group and the Framework for U.S. Stewardship and Governance' https://isgframework.org/ accessed 25 Nov. 2019.

${ }^{28}$ Investor Stewardship Group 'signatories' https://isgframework.org/signatoriesand-endorsers/ accessed 25 Nov. 2019.

${ }^{29}$ Id.

${ }^{30}$ Hill, supra note 1 at $510-11$.

${ }^{31}$ Investor Stewardship Group, 'About the Investor Stewardship Group and the Framework for U.S. Stewardship and Governance' https://isgframework.org/. accessed 25 Nov. 2019. The ICG's stewardship principles can be found here: https://isgframework.org/stewardship-principles/

32 'Investor Stewardship Group Achieves Remarkable Success in its First Year' Businesswire (18 Dec. 2018) https://www.businesswire.com/news/home/20181218005480/en/InvestorStewardship-Group-Achieves-Remarkable-Success-Year 
stewardship activities of asset managers. And the governance principles endorsed by the ISG do not appear to extend significantly beyond existing legal requirements or minimum standards. ${ }^{33}$ The stewardship principles are similarly limited. ${ }^{34}$ Although the ISG adopted the framework in the wake of criticisms by commentators that some U.S. instituional investors (and in particular, three of the ISG signatories - BlackRock, Vanguard and State Street) are devoting insufficient effort to governance and stewardship, ${ }^{35}$ the principles are not binding on either issuers or signatories. ${ }^{36}$ Indeed, the ISG website explicitly notes that signatories retain the discretion to "implement the stewardship principles in a manner they deem appropriate." 37

An additional concern about the ISG framework its failure to define the objectives of investor stewardship explicitly or to designate the extent to which institutional investors can or should incorporate objectives other than wealth maximization into the stewardship function. ${ }^{38}$ Although a growing number of investors and policymakers are arguing that investor stewardship includes attention to non-shareholder stakeholders and social policy goals as well as economic value, and stewardship codes increasing reference these goals, they provide little guidance as to how a responsible steward is supposed to strike a balance between competing economic and non-economic objectives or between shareholders and other stakeholders.

These issues are highlighted in the case of passive investment vehicles such as index funds. Although these investment vehicles hold title and exercise

${ }^{33}$ For example, Principle 1 states that "Boards are accountable to shareholders", a principle that is reflected in existing statutory and common law principles such as fiduciary duties and the power of shareholder to elect and remove directors.

34 Principle A of the Stewardship Framework, for example, states that "Institutional investors are accountable to those whose money they invest," a principle that is inherent in the legal status of asset managers and other institutional investors as fiduciaries.

${ }^{35}$ See, e.g. Bebchuk \& Hirst, supra note 6, working paper at 11 (identifying the "the shortcomings of current stewardship decisions" by index funds); Dorothy Lund 'The Case Against Passive Shareholder Voting' (2018) 43 Iowa J. Corp. L. 493, 497("passive funds have failed to act as seriously engaged owners").

${ }^{36}$ In describing the ISG, Hill observes that "The Walker Review's clear message was that regulator/quasi-regulator-sanctioned codes have more clout than investorled codes." Hill, supra note 1 at 510 .

${ }^{37}$ ISG, About the Investor Stewardship Group, supra note 31.

${ }^{38}$ See Bernard S. Sharfman, 'The First Critique of the "Framework for U.S. Stewardship and Governance"” (2017) https://www.law.ox.ac.uk/business-lawblog/blog/2017/11/first-critique-framework-us-stewardship-and-governance (arguing that "as stewards, the objective of such management must be wealth maximization."). 
voting rights with respect to an increasing percentage of global equity and are particularly important for their growing ownership of the U.S. equity markets, their distinctive structure and business model provide practical limitations on their potential effectiveness as corporate stewards. The risk of imposing extensive stewardship obligations on index funds is that it may have the consequence of reducing the viability of index funds as an investment tool for unsophisticated retail investors, creating demands for managerial decisions that constrain efficient corporate decision-making, or introducing additional agency costs. As a result, this chapter suggests caution in effort to expand institutional investor stewardship obligations.

\section{THE BUSINESS MODEL OF INDEX FUNDS}

This chapter focuses on a particular segment of the institutional investor market - index funds. Index funds are a type of mutual fund, an investment vehicle that consists of a pool of assets managed by an investment adviser pursuant to an advisory agreement. In the case of an index fund, the advisory services provided are minimal because the fund's investment strategy is simply to track the return of a designated index such as the Dow Jones Industrial Average or the S\&P 500. ${ }^{39}$ There are thousands of potential indexes, but the majority of assets are invested in funds that track the most popular indexes. ${ }^{40}$ Thus, for example, the DIA ETF, which is offered by State Street Asset management, seeks to provide investment returns that track those of the Dow Jones Industrial Average, and currently consists of approximately $\$ 22$ billion in assets under management. ${ }^{41}$

Estimates vary as to the precise percentage of equity held by index funds; one estimate from 2017 indicated that index funds hold approximately $18 \%$ of the global stock market. ${ }^{42}$ That number continues to grow. Within the mutual fund industry, funds that passively track an index will, if current trends continue,

\footnotetext{
${ }^{39}$ For a more complete discussion of the structure of index funds, see Fisch, et al., supra note 17.

${ }^{40}$ For a comprehensive explanation of the creation and structure of indexes and index funds see Adriana Z. Robertson, 'Passive in Name Only: Delegated Management and "Index" Investing' (2019) 36 Yale J. on Reg. 795.

${ }^{41}$ State Street Global Advisors, SPDR $®$ Dow Jones ${ }^{\circledR}$ Industrial Average ETF Trust, https://us.spdrs.com/en/etf/spdr-dow-jones-industrial-average-etf-trust-DIA accessed 25 Nov. 2019.

${ }^{42}$ Trevor Hunnicutt, 'Less than 18 percent of global stocks owned by index investors: BlackRock' (3 Oct. 2017) Reuters, https://www.reuters.com/article/usfunds-blackrock-passive/less-than-18-percent-of-global-stocks-owned-by-indexinvestors-blackrock-idUSKCN1C82TE
} 
top $50 \%$ of U.S. stock funds within $2019 .{ }^{43}$ Moreover, with the growth of passive investing, the mutual fund industry has experienced substantial concentration such that most mutual fund assets are invested by the top 3 or 4 mutual fund companies. In turn, BlackRock, Vanguard, State Street and Fidelity collectively own as much as 15 or $20 \%$ of the large public companies. ${ }^{44}$

Two aspects of the index fund model are particularly relevant in evaluating their potential to engage in effective stewardship. The first is that, because the investment model of index funds is passively to track an index, the advisers of the fund have no reason to engage in firm-specific research and analysis to informm their investment decisions. In contrast to active managers, hedge funds and other stock pickers, index funds do not, indeed they cannot, trade on the basis of information. Rather than the potential opportunity to beat some designated benchmark, index funds offer their investors a market rate of return. Because they are designed to replicate the returns of what is typically a broad-based index, these funds also offer their investors substantial diversification.

The second aspect of the index fund model that is relevant to its potential for effective stewardship is its fee structure. Because they do not rely on costly firm-specific research, index funds incur lower management costs, and they pass these reduced costs on to mutual fund investors in the form of very low fees. Because funds that track the same index will, if properly designed, produce nearidentical returns, a fund sponsor cannot distinguish itself in terms of the skill of its advisers. Nor can a sponsor charge a premium for adviser quality. The result is that the fees charged by index funds to investors are very low and substantially lower than those of actively-managed funds. Indeed, in 2018, Fidelity introduced four no-fee index funds. ${ }^{45}$ The combination of low cost and diversification makes index funds a popular tool for retirement accounts, and a substantial proportion of the assets under management in index funds are retirement savings, a subject to which this chapter will return in Part V below.

\section{PASSIVE INVESTORS AND FIRM OVERSIGHT}

${ }^{43}$ Charles Stein, 'Shift from Active to Passive Approaches Tipping Point in 2019, [2018] Bloomberg, https://www.bloomberg.com/news/articles/2018-12-31/shiftfrom-active-to-passive-approaches-tipping-point-in-2019

${ }^{44}$ See Fichtner, et al., supra note 13, at 298, 304 (presenting data on size and holdings of the largest US asset managers and showing that BlackRock, Vanguard, State Street and Fidelity were the four largest as of June 2016).

${ }^{45}$ Eric Rosenbaum, 'Who won the zero-fee ETF war? It looks like no one' $C N B C$ (10 Oct. 2019), https://www.cnbc.com/2019/10/10/who-won-the-zero-fee-etf-warit-looks-like-no-one.html (reporting that Fidelity "launched four core index mutual funds at no fee,"). 
As the preceding discussion explains, neither index funds nor the investment advisers who manage them necessarily acquire any firm-specific information about their portfolio companies in connection with the decision to invest in those companies. Unlike the prototypical rational investor which evaluates the information available in the market in order to make an informed investment decision, index fund advisers mechanically cause the fund to invest in the securities necessary to match the return of the designated index. While the fund buys and sells securities on a regular basis - to meet purchase and redemption requests, to rebalance as necessary and to adjust to changes in the underlying index - those transactions are mechanical and non-discretionary.

The irrelevance of information to index fund trading makes index funds an anomaly with respect to federal securities regulation which creates a disclosure regime designed to enable investors to make informed trading decisions. Indeed, the threshold criterion for defining securities disclosure obligations is the concept of materiality which is defined as information such that there is a "substantial likelihood that a reasonable shareholder would consider it important in making an investment decision." ${ }^{46}$ From the perspective of an index fund, the disclosures made by its portfolio companies are arguably irrelevant, at least with respect to the fund's investment decisions.

Index fund sponsors would, of course, challenge the claim that they do not use or benefit from corporate disclosures. They use disclosures to make informed voting decisions, and, increasingly, they engage with their portfolio companies in an effort to improve their corporate governance, risk management and economic success. ${ }^{47}$ Although commentators disagree as to whether passive funds exert sufficient effort with respect to these initiatives and whether their efforts lead to improved firm performance, there is little question that index fund sponsors and advisers are devoting increasing resources to stewardship. Indeed, the call for increased stewardship - from both academics and policymakers - is premised on the expectation that those efforts should be increased.

Some academics question whether those demands are cost effective. ${ }^{48}$ Specifically, for stewardship to have a meaningful impact on a firm-specific

${ }^{46}$ Basic Inc. v. Levinson, 485 U.S. 224, 231 (1988) (quoting TSC Indus., Inc. v. Northway, Inc., 426 U.S. 438, 449 (1976)).

${ }^{47}$ Voting levels have increased. Index funds are likely to be at least as effective as many other types of shareholders such as retail investors and algorithmic traders at rationally voting their shares. In most cases, the level of firm-specific information necessary to make an informed voting decision is relatively limited.

${ }^{48}$ See, e.g., Dorothy S. Lund, 'Nonvoting Shares and Efficient Corporate Governance' (2019) 71 Stan. L. Rev. 687, 696 (arguing that index funds should not vote in corporate elections because it is not cost-effective for them to incur expenditures to monitor their portfolio companies). 
basis - by reducing managerial agency costs, improving operational decisionmaking or modifying firm structure -- investors require firm-specific information to identify existing deficiencies and to evaluate, within the context of the firm's operations, appropriate changes to address those deficiencies. In addition to acquiring information, investors must develop the necessary expertise to evaluate that information such that their challenges are reliable. ${ }^{49}$ As Ron Gilson explained: "for investors, distinguishing between shortsighted and well-disciplined managements - and between farsighted companies and those for whom the payoff will never materialize — is often impossible." 50

Firm-specific engagement aimed at disciplining management or identifying value-enhancing structural or operational changes exists in today's markets; indeed, it is precisely the business model of the activist hedge fund. Hedge funds invest in portfolio companies with the plan of evaluating firmspecific information and proposing structural or operational changes designed to improve firm performance. Although commentators debate the extent to which hedge fund activism contributes to sustainable economic value as opposed to relying on short term strategies that conflict with the interests of long-term holders, ${ }^{51}$ hedge funds may be, may be considered high-powered investor stewards. ${ }^{52}$

Although one can debate whether hedge fund activism is fairly categorized as stewardship, at least when stewardship is focused on maximizing economic value and reducing agency costs, the debate is largely semantic. ${ }^{53}$

\footnotetext{
${ }^{49}$ Some actively managed firms are going on the offensive. Schroders published a report in September 2018 saying passively managed funds lacked the resources for reliable research on whether companies live up to ESG standards. The report said these lower-cost funds lack the "specialist knowledge" needed to lobby the boards of portfolio companies for ESG changes. Schroders, "ESG in passive: let the buyer beware' [2018] https://www.schroders.com/en/insights/economics/esg-in-passivelet-the-buyer-beware/. "There doesn't appear to be a cheap way to get real sustainability," said Jessica Ground, the global head of stewardship at Schroders. Id.

${ }^{50}$ Ronald Gilson, 'Legal and Political Challenges to Corporate Purpose' (2019) 31

J. App. Corp. Fin 1, 9

${ }^{51}$ See, e.g., Dionysia Katelouzou, 'Hedge Fund Activism and Shareholder Stewardship: Incompatible, Reciprocal or Something in Between?' (forthcoming) (citing empirical debate over the effect of hedge fund activism on the long term value of portfolio companies).

${ }^{52}$ See, e.g., id. (evaluating activism by UK hedge funds within stewardship framework); Jill E. Fisch \& Simone Sepe 'Shareholder Collaboration' (forthcoming 2020) _ Tex. L. Rev. _ (describing collaborative role of hedge funds).

${ }^{53}$ This chapter considers the question of whether stewardship should ecompass non-economic or non-shareholder objectives below.
} 
What makes it feasible for hedge funds to engage in effective stewardship? Three factors are key. First, hedge funds invest in a limited number of portfolio companies and take a substantial economic position in each. As a result, a hedge fund has the potential to receive a substantial benefit from its engagement, both in absolute terms and as a proportion of the overall value of the fund. For example, hedge fund Trian Partners invested $\$ 3.5$ billion of its $\$ 12.7$ billion fund in Proctor \& Gamble. ${ }^{54}$ The hedge fund's lack of diversification also minimizes the free rider effect - although other shareholders in the target company may benefit from the activism, they will not benefit to the same degree as the hedge fund. ${ }^{55}$ Second, hedge funds can devote substantial resources to gathering the type of firm-specific information necessary to engage in effective stewardship. ${ }^{56}$ The standard hedge fund fee structure pays the fund advisers $2 \%$ of assets under management and $20 \%$ of profits, making it cost-effective for substantial activism-based expenditures. ${ }^{57}$ Third, hedge funds have specialized knowledge. They hire managers and employees that can offer firm and industry expertise. ${ }^{58}$

All three of these features are absent from the index fund business model. Index funds offer broad diversification; the very point of an index fund is to provide its investors with broad market exposure rather than a selected small group of stocks. Index funds offer their investors very low fees; in fact, the market appeal of the index fund is its potential to charge less than activelymanaged funds. Finally, given that index funds do not engage in informationbased investment decisions, they derive limited value from paying to develop firm or industry expertise. As a result, there is a substantial risk that index funds

${ }^{54}$ Berkeley Lovelace, Jr., Billionaire Nelson Peltz: P\&G is making my board battle the "dumbest thing I've ever been involved in"' (6 Oct. 2017) CNBC.com https://www.cnbc.com/2017/10/06/billionaire-activist-peltz-my-proxy-fight-withprocter-gamble-will-be-close.html

55 This distinguishes hedge funds from mutual funds. See, e.g., Lund, supra note 48 (identifying the free rider concern as a limit on index fund engagement).

${ }^{56}$ See, e.g., Zsolt Katona, Marcus Painter, Panos Patatoukas \& Jean Zeng 'On the Capital Market Consequences of Alternative Data: Evidence from Outer Space' (July 30, 2018). https://ssrn.com/abstract $=3222741$ (describing persistent abovemarket returns that hedge funds can obtain through their purchase and use of costly satellite data of store parking lots).

${ }^{57}$ For example, Trian spent an estimated $\$ 25$ million in its proxy fight with Proctor \& Gamble. Barrett J. Brunsman 'P\&G expects proxy battle to cost $\$ 35$ million' (2 Aug. 2017) Cincinnati Business Courier https://www.bizjournals.com/cincinnati/news/2017/08/02/p-g-expects-proxybattle-to-cost-35-million.html

${ }^{58}$ See C.N.V. Krishnan et al., 'The Second Wave of Hedge Fund Activism: The Importance of Reputation, Clout, and Expertise' (2016) 40 J. CORP. FIN. 296 (providing empirical evidence that successful activists bring expertise to their engagements). 
will impose what Zohar Goshen and Richard Squire term "principal competence costs" - "mistakes due to a lack of expertise, information, or talent."59

Concededly index funds can, and increasingly do, engage in some level of stewardship that is cost-effective within their existing business model.$^{60}$ They can develop expertise with respect to corporate governance issues that affect a substantial proportion of companies in their portfolios. They can identify and evaluate market-wide trends and risks such as climate change and cybersecurity and can call upon those companies that lag to adopt the best practices of industry leaders. ${ }^{61}$

Notably, even this level of engagement may present challenges. ${ }^{62}$ For example, although it seems uncontroversial to call for index funds to demand better governance from their portfolio companies, experts often disagree both on what constitutes good governance and on the relationship of specific governance features to firm economic value. Thus, while index funds have championed director independence, and institutional investor pressure has led issuers to boards that are almost entirely independent of management, empirical evidence has failed to establish a connection between board independence and firm economic value. ${ }^{63}$ Similarly, index funds were among the investors who, through the Harvard shareholder rights project, sought to persuade their portfolio companies to eliminate their staggered boards. ${ }^{64}$ Yet the empirical evidence on the impact of staggered boards is mixed, and research suggests that staggered

${ }^{59}$ Zohar Goshen \& Richard Squire, 'Principal Costs: A New Theory for Corporate Law and Governance' (2017) 117 Colum. L. Rev. 767, 770.

${ }^{60}$ It is beyond the scope of this chapter to address the potential that index funds, or mutual funds generally, will limit their stewardship out of a desire to further other business relationships with their portfolio companies such as the opportunity to manage their 401(k) plans. See, e.g., Gerald F. Davis \& E. Han Kim, Business Ties and Proxy Voting by Mutual Funds, 85 J. Fin. Econ. 552, 553 (2007) (noting the argument that mutual funds that manage corporate pension plans may be more "acquiescent to existing governance practices").

${ }^{61}$ See Fisch, et al., supra note 17 (describing engagement efforts by the large index fund providers).

${ }^{62}$ See Alicia Davis, 'The Institutional Appetite for "Quack Corporate Governance"' (2015) Columbia Business Law Review 11-12 (finding that institutional investors mistakenly believe high-quality internal governance devices to be value-enhancing).

${ }^{63}$ Sanjai Bhagat \& Bernard Black, 'The Uncertain Relationship Between Board Composition and Firm Performance' (1999) 54 Bus. Law. 921, 924, 933.

${ }^{64}$ Daniel Gallagher and Joseph Grundfest, Did Harvard Violate Federal Securities Law? The Campaign Against Classified Boards of Directors (Rock Center for Corporate Governance at Stanford University Working Paper No. 199, Dec. 4, 2014), available at https://bit.ly/2IE1bEu. 
boards can be value-enhancing in some cases. ${ }^{65}$ It is well known that institutional investors were a leading force in the shift to making executive pay structures more performance-based, but stock options, a popular feature of early performance-based structures, turned out to have create problematic incentives for executives to take excessive risk. ${ }^{66}$ Most recently, index funds have been vocal opponents of dual class stock structures, and the Council of Institutional Investors has urged exchanges and regulators to ban or limit dual class. ${ }^{67}$ Again, however, the empirical data fails to support the claim that dual class stock reduces firm value. ${ }^{68}$

One problem with broad-based governance initiatives is the possibility that the effect of governance is firm-specific and that, as a result, determining whether a governance reform will enhance value at a particular company requires firm-specific knowledge. ${ }^{69}$ This in turn, increases the cost of effective stewardship. To the extent that one cannot reliably ascertain the economic impact of particular governance models or structures, either in general or with respect to individual firms, it may be rational for index funds to adopt a diversified market-wide approach to governance.

Assuredly index funds could devote greater resources to stewardship to address these concerns. Index funds could sponsor shareholder proposals, serve as lead plaintiffs in shareholder litigation and meet with officers and directors at a greater percentage of their portfolio companies. Index funds could hire investment advisers with firm and industry expertise and pay those advisers to devote more hours to acquiring and evaluating firm-specific information. But

${ }^{65}$ Id.; Cremers \& Simone Sepe, 'The Shareholder Value of Empowered Boards' (2016) 68 Stan. L. Rev. 67, 71-72.

${ }^{66}$ See, e.g., Zhiyong Dong et al., 'Do Executive Stock Options Induce Excessive Risk Taking?' (2010) 34 J. BANK. \& FIN. 2518, 3-16 (discussing whether executive stock options induce excessive risk taking by managers).

${ }^{67}$ See, e.g., Council of Institutional Investors, 'CII Welcomes S\&P Dow Jones' Decision to Ban New Multi-Class Companies from Key Stock Indexes' (2017) https://www.cii.org/spdjmulticlassban (explaining that "The Council of Institutional Investors (CII) welcomes S\&P Dow Jones' decision to ban new multiclass companies from its key U.S. stock indexes")

${ }^{68}$ See George David Banks \& Bernard Sharfman, 'Standing Up for the Retail Investor' (2018), Harv. Law School Forum on Corporate Governance and Financial Regulation, https://corpgov.law.harvard.edu/2018/06/10/standing-up-forthe-retail-investor/ (criticizing institutions for advocating the elimination of dual class stock despite the economic success of companies like Google, Facebook and Berkshire Hathaway.

${ }^{69}$ See, e.g, Matthew D. Cain, Jill E. Fisch, Sean J. Griffith \& Steven Davidoff Solomon, How Corporate Governance is Made: The Case of the Golden Leash' (2016) 164 U. Pa. L. Rev. 649, 697 (providing empirical evidence supporting "the proposition that corporate governance should be decided on a firm-by-firm basis"). 
these efforts are costly. While index fund providers could potentiallly distinguish themselves on the basis of their stewardship activities and thereby justify charging higher fees, it is unclear at present whether investors will be willing to pay a premium to invest in funds that engage in greater stewardship. Even if they are, it is unclear whether index funds are the most efficient providers of firm-specific monitoring.

\section{INDEX FUNDS AND STEWARDSHIP OBJECTIVES}

Determining the appropriate objectives of investor stewardship adds an additional complication. The original UK Stewardship code did not definte stewardship or its objectives. ${ }^{70}$ That omission has been remedied, and today, in both the UK and the EU, most calls for institutional investor stewardship do not restrict themselves to encouraging investors to seek to enhance the economic value of their portfolio companies but instead urge a broader focus on nonshareholder stakeholders or the public interest. ${ }^{71}$ This broader focus is reflected in the 2020 UK Code, which adopts a definition of "stewardship that creates longterm value for clients and beneficiaries leading to sustainable benefits for the economy, the environment and society." 72

This mandate complicates the decision-making framework for funds and their advisers as well as placing additional demands on fund expertise. How are funds and their managers to determine which societal values warrant attention? How are fund decisionmakers to weigh the potentially competing interests of the customers, suppliers, employees and communities affected by the operations of their portfolio companies and to balance those interests against shareholder economic value ${ }^{73}$ Although increasing the sustainability of a firm's operations

\footnotetext{
${ }^{70}$ Reisberg, supra note .

${ }^{71}$ See Dionysia Katelouzou, 'Shareholder stewardship: a case of (re)-embedding the institutional investors and the corporation?' ('Outside the USA, the currently prevailing narrative, especially in policy circles, views shareholder engagement as a desirable corporate governance attribute able not only to improve corporate governance and performance, but also to ensure long-term stability and social responsibility")

722020 Stewardship Code at 8 , Principle 1. The Code goes on to explain that "Signatories systematically integrate stewardship and investment, including material environmental, social and governance issues, and climate change, to fulfil their responsibilities." Id. at 15, Principle 7.

${ }^{73}$ See Stephen M. Bainbridge 'In Defense of the Shareholder Wealth Maximization Norm: A Reply to Professor Green' 50 Wash \& Lee L. Rev. 1423, 1436 (explaining that this role is analogous to the untenuous competing duties imposed on a "lawyer for the situation").
} 
may enhance firm economic value, there are reasons to reasons to question the consistent alignment of societal objectives with profit maximization. ${ }^{74}$

Stewardship addressed to a broader range of objectives also exacerbates the agency problem faced by index funds and their advisers as intermediaries for investors in the funds. The problem posed is similar to the one debated eighty years ago between Adolph Berle and Merrick Dodd. Dodd argued broadly that corporate managers had a responsibility to operate their businesses in the interests of the general public. ${ }^{75}$ Berle responded, not out of an opposition to the general idea that corporations should have a public responsibility but to a broad view of managerial discretion that would leave it unconstrained. ${ }^{76}$ Investor stewardship raises similar concerns. If advisers use fund engagement to maximize the fund's economic value, investors in that fund have metrics to evaluate whether that engagement is successful and cost-justified. At the present, however, the metrics for evaluating the social responsibility of a portfolio company or a socially responsible investment fund are problematic as many commentators have observed, sustainability disclosures are limited, incomplete and largely unreliable. ${ }^{77}$

Obligating investment managers to incorporate broad-based stewardship objectives also increases the risk of self-dealing. ${ }^{78}$ As with corporate

${ }^{74}$ See Leo E. Strine, Jr. 'Our Continuing Struggle with the Idea that For-profit Corporations Seek Profit' [2012] 47 Wake Forest L. Rev. 135 ("the cost, simplistic, and single-minded, short-term focus of stockholders on stock price may result in outcomes that, from a broader societal perspective, are deeply uncomfortable.")

${ }^{75}$ E. Merrick Dodd, Jr., 'For Whom Are Corporate Managers Trustees?' (1932) 45

Harv. L. Rev. 1145, 1148 (arguing that corporations that corporations have a "social service [responsibility] as well as a profit-making function.").

${ }^{76}$ See, e.g., William W. Bratton \& Michael L. Wachter, 'Shareholder Primacy's Corporatist Origins: Adolf Berle and The Modern Corporation,' (2008) 34 Iowa J. Corp. L. 99, 129 (explaining that "To make managers trustees for the community would free them of any meaningful constraint because almost all corporate activity could be justified in the interests of one group or another.").

${ }^{77}$ See, e.g., Jill E. Fisch, 'Making Sustainability Disclosure Sustainable' (2019)

107 Geo. L. J. 924, 926 (critically observing that sustainability disclosures are neither standardized nor audited and that issuers vary substantially in the information they provide); Jon Sindreu \& Sarah Kent, 'Why It's So Hard to Be an 'Ethical' Investor' (1 Sept. 2018) Wall St. J. https://www.wsj.com/articles/why-itsso-hard-to-be-an-ethical-investor-1535799601 $\mathrm{mod}=? \mathrm{mod}=\mathrm{itp} \& \mathrm{mod}=$ djemITP $\mathrm{h}$ [https://perma.cc/K7EH-EBUG]. (observing that "A Journal analysis of four leading ESG ratings providers found that they come to completely different conclusions about what makes a company a "sustainable" investment.").

${ }^{78}$ As Leo Strine observes, although Henry Ford defended his decision not to pay corporate dividends as improving social welfare, "Ford's desire to deny [the Dodge 
managers, ${ }^{79}$ the heads of institutional intermediaries may "use other people's money to advance their own view of the good." ${ }^{80}$ There is little reason to think that fund managers have particular expertise in identifying the most appropriate social goals, and there is a realistic possibility that the goals they advocate may instead be controversial or unique. ${ }^{81}$ At the same time, the substantial voting power exercised by the large mutual fund companies gives leaders like Larry Fink at BlackRock a "bully pulpit" 82 to take public positions that cause some to acclaim him as a "visionary" ${ }^{3}$ despite the fact that, if the principles he advocates sacrifice economic value, it is the customers in BlackRock's funds who will bear the cost.

Asset managers also face competing incentives. Advocating social responsibility may help asset management firms resist regulatory interventions motived by fears of their growing power. A firm that is publicly associated with social responsibility may be more attractive to an employer as the administrator of company 401(k) plans. A mutual fund company may favor social policies at their portfolio companies that sacrifice returns to attract discretionary investments by some investors even if other investors prefer decisions motivated exclusively by economics. A critical component of the trade-off among investors is that mutual funds manage a substantial quantity of retirement investments, many of which are owned by unsophisticated employees who are defaulted into their employer's choice of 40 ! (k) investment option and face the real prospect of having inadequate retirement savings if the economic returns of their investments are not maximized.

In addition, there are reasons to believe that even well-intentioned and unconflicted asset managers may be imperfect proxies for the interests of their beneficiaries. Scholars have identified significant differences between the

Brothers] dividends that could be used to fund their own eponymous car manufacturing operations might have also contributed to Henry Ford's highmindedness." Strine, supra note 74, n. 32

${ }^{79}$ As Stephen Bainbridge observes "The real object and purpose of a corporation for profit is to make a profit and to make dividends for the stockholders, and a person who holds the stock of a company has a right to have the business of the company conducted, as far as practicable at least, so that it will make profits and pay dividends." Steven Bainbridge, A Predecessor to Dodge v. Ford Motor Co., (2019) https://www.professorbainbridge.com/professorbainbridgecom/2019/07/apredecssor-to-dodge-v-ford-motor-co.html citing Arbuckle v. Woolson Spice Co., 1901 WL 708, at *2 (Ohio Cir. Ct. Jan. 12, 1901).

${ }^{80}$ Strine, supra note 74 .

${ }^{81}$ Id.

${ }^{82}$ Peter Georgescu, 'Fink Swims Against the Sharks' [2019] Forbes, https://www.forbes.com/sites/petergeorgescu/2019/05/30/fink-swims-against-thesharks/\#51da2d865dde

${ }^{83}$ Id. 
voting preferences of retail and institutional investors on a variety of issues from election of directors and executive compensation to support for shareholder proposals. ${ }^{84}$ Particularly worrisome in this regard is the fact that one of the largest gaps is with respect to sustainability and ESG issues. As one study reported, environmental and social proposals were supported by 29 percent of institutional investors but only 16 percent of retail investors. ${ }^{85}$

Although retail voting patterns suggest that mutual fund voting currently favors ESG issues more than the voting of retail investors, ${ }^{86}$ some commentators assert that investors will sacrifice return in favor of principles. ${ }^{87}$ Recent asset flows support this, finding increasing investor demand for ESG-conscious index funds even though the cost of such funds is significantly higher than other index funds. To the extent that fund beneficiaries are willing to pay for fund stewardship, the prospect of more effective index fund stewardship increases dramatically. On the other hand, studies also suggest that retail investors do not support their asset managers sacrificing returns in favor of social policy initiatives. $^{88}$ One possibility is to retain the low costs of an index-based

${ }^{84}$ Ning Chiu, 'How Do Retail Shareholders Vote?' [2018] Davis Polk, Briefing:

Governance https://www.briefinggovernance.com/2018/10/how-do-retailshareholders-vote/ (finding substantial greater support by institutional investors for social and environmental proposals than by retail investors); Gretchen Morgenson, 'Small Investors Support the Boards. But Few of Them Vote.' [2017[ New York Times, https://www.nytimes.com/2017/10/06/business/small-investors.html (reporting on an analysis of shareholder voting that found "a striking contrast between the views of institutional investors and those of individuals")

${ }^{85}$ Main Street Investors Coalition, 'Proxy Advisor Recommendations Ignore the Views of Retail Investors' [2018[ https://mainstreetinvestors.org/proxy-advisorrecommendations-ignore-the-views-of-retail-investors/

${ }^{86}$ Some reports nonetheless criticize mutual funds, particularly ESG funds, for voting records that do not show greater support for ESG proposals. See, e.g., Lewis Braham, Sustainability Ratings Tell Half the Story' [2017] Barron's, https://www.barrons.com/articles/sustainability-ratings-tell-half-the-story$1507350027 /$ Unfortunately because most analyzes of fund voting evaluate proposals by category rather than the substance of the proposal, they risk presenting a misleading picture of fund voting policies. See, e.g., Fund Votes, https://www.fundvotes.com/votingtrends/. Thus, for example, Fund Votes' presentation of voting data on environmental, social and governance proposals seems to assume that an ESG-oriented fund would properly support $100 \%$ of shareholder proposals on those topics irrespective of their content.

${ }^{87}$ See Gilson, supra note _ at 12 (predicting they will)

${ }^{88}$ See Main Street Investors Coalition, supra note _. In an analogous survey of pension fund beneficiaries " $86 \%$ of CalPERS members and $79 \%$ within NYC Funds indicated their pension fund should be focused on generating returns and shouldn't be making investment decisions on the basis of politics even if they 
investment strategy while committing the fund to a more ESG-oriented voting policy. ${ }^{89}$ Indeed, Institutional Shareholder Services (ISS) offers a specialty set of socially responsible investment voting guidelines..$^{90}$ Although such a fund's voting approach must be relatively inflexible to limit costs, ${ }^{91}$ the approach offers mutual fund customers a cost-effective way of increasing the social orientation of their investments. Notably, however, it does so by transfering the task of determining appropriate social policy from asset managers to ISS, a delegation that has been criticized in other contexts. ${ }^{92}$

\section{THE ROLE OF FUND BENEFICIARIES}

One possible solution to the agency problem is empowering mutual fund beneficiaries to determine or oversee the stewardship objectives of their asset managers. This could be done at the entity level through shareholder voting on or approval of fund stewardship policies or at the beneficiary level through the implementation of pass-through voting. This section questions the efficacy of either approach.

As early as the 1970s, the SEC expressed concern about the growing institutionalization of the public equity markets and the effect of that institutionalization on proxy voting. ${ }^{93}$ Among its concerns was the fact that

support the idea or cause." Spectrem Group, 'Tensions with Pensions: An Analysis of Public Pension Fund Members' Knowledge and Sentiment about How Their Money Is Being Invested' [2018]

${ }^{89}$ Gina Rao has made such a proposal. See Gina Rao, 'Give mutual fund investors a voice in shareholder proxy voting' (2017) MarketWatch, https://www.marketwatch.com/story/give-mutual-fund-investors-a-voice-inshareholder-proxy-voting-2017-12-12 (advocating an index fund that commits in its prospectus to follow an ESG voting policy).

${ }^{90}$ See Institutional Shareholder Services, 'United States SRI Proxy Voting Guidelines 2019 Policy Recommendations' (2019)

https://www.issgovernance.com/file/policy/active/specialty/SRI-US-VotingGuidelines.pdf

${ }^{91}$ See Andrey Malenko \& Nadya Malenko, 'Proxy Advisory Firms:

The Economics of Selling Information to Voters' (2019) 5 J. Fin. 2441 (noting the "one-size fits all" criticism of proxy advisor recommendations).

92 See, e.g., David Larcker \& Allan McCall, 'Outsourcing Shareholder Voting to Proxy Advisory Firms' (2015) 58 J.L. \& Econ. 173, 203 ("The outsourcing of voting to proxy advisory firms appears to have the unintended economic consequence that boards of directors are induced to make choices that decrease shareholder value.").

${ }^{93}$ See Proposed Rules Relating to Shareholder Communications, Shareholder Participation in the Corporate Electoral Process and Corporate Governance Generally, (1978) Securities Exchange Act Release No. 14970, 1978 SEC LEXIS $1127, * 31$ (noting that, "major institutions held, as at the end of 1977, more than 
institutional voting might not reflect the views of those with the true economic interest in the shares. In 1978, the SEC explicitly considered the desirability of obtaining these views "by means of a polling or pass-through voting requirement." 94 At that time, the SEC reported that "substantially all of the commentators who addressed the issue ... were opposed to such a requirement" citing suggestions that the undertaking would be costly and difficult and that fund shareholders were unlikely to have an interest in or desire to vote on the issues affecting their portfolio companies. ${ }^{95}$

Subsequent technological developments have reduced the cost and difficulty of pass-through voting. Leading to to renewed calls for pass-through voting. ${ }^{96}$ For example, Jennifer Taub has argued that pass-through voting would enable fund beneficiaries to overcome the passivity of fund advisers. ${ }^{97}$ Dorothy Lund argues that pass-through voting would reduce the "incidence of uninformed voting." 98 Caleb Griffin suggests that mutual funds could use standing voting instructions to democratize index fund voting either by enabling fund beneficiaries to complete an issue-based survey that would form the basis for the beneficiary's proxy voting guidelines or by stipulating in advance that their votes should mirror those of a proxy advisor or another institutional investor. ${ }^{99}$

These commentators accurately highlight the potential for pass-through voting to reduce agency costs, and technological advances such as internet

$33 \%$ of the total stock outstanding in the United States.). Ironically, the number today is closer to $70 \%$ ).

${ }^{94}$ Id., 1978 SEC LEXIS 1127, *33-34

${ }^{95}$ Id.

${ }^{96}$ See, e.g., John C. Coffee, Jr., 'Brave New World?: The Impact(s) of the Internet on Modern Securities Regulation' (1997) 52 Bus. Law. 1195, 1210-13 (observing that "on the longer-term horizon, there is even the visionary possibility that the Internet can be used to pass through voting rights in securities held by pension and mutual funds to the fund's own owners or beneficiaries"); John C. Wilcox, Electronic Communication and Proxy Voting: The Governance Implications of Shareholders in Cyberspace' [1997] Insights 8, 11 (discussing company communications with investors through new electronic media and wondering whether "pass-through voting" for investors in pension funds and mutual funds will develop). Indeed, there has been some development of pass-through voting in pension plans. James A. Fanto, 'Investor Education, Securities Disclosure, and the Creation and Enforcement of Corporate Governance and Firm Norms' (1998) 48 Cath. U.L. Rev. 15, 35. N. 79 (observing that "pass-through voting has developed within both defined contribution and defined benefit pension plans")

${ }^{97}$ Jennifer S. Taub 'Able but Not Willing: The Failure of Mutual Fund Advisers to Advocate for Shareholders' Rights' (2009) 34 IOWA J. CORP. L. 843, 888-89

${ }^{98}$ Lund, supra note __ at 530.

${ }^{99}$ Griffin, supra note 
voting make pass-through substantially less difficult to implement than it was in the 1970s. The fact remains, however, that mutual fund investors are poorly positioned to direct the proxy voting of their proportionate interest in the fund's portfolio companies. Addressing the complex questions necessary to formulate an effective stewardship policy are even harder.

In understanding this point, it is important to keep the characteristics of retail mutual fund investors in mind. In 2018, individual investors held $89 \%$ of mutual fund assets. Mutual fund investors differ from other retail investors. They select their mutual funds, in the best case scenario on the basis of investment style and cost and, in the worst case, on the basis of less rational criteria such as the name of the fund. Typically they do not engage in firmspecific research into the portfolio companies held by the mutual funds in which they invest; indeed, in most cases they are unlikely to know the portfolio companies in which the mutual fund is invested. Their very purpose, in choosing a mutual fund, is to delegate investment discretion to the fund manager.

Further, retail investors hold a substantial percentage of their mutual fund investments in retirement accounts that have distinctive characteristics. In 2018, $94 \%$ of mutual fund investors held their funds inside employer-sponsored retirement plans, IRAs and variable annuities. ${ }^{100} 37 \%$ of households held mutual funds exclusively through employer-sponsored retirement plans and, in many cases assets held outside such plans were the result of $401(\mathrm{k})$ rollovers. ${ }^{101}$ The purchase of a mutual fund in a 401(k) is different from a market-based investment decision. Although plan participants choose the specific funds in which they invest, that choice is limited by the menu of investment options selected by the employer. In addition, an increasing number of employers enroll their employees into their retirement plans automatically. ${ }^{102}$ The money of those employees is invested in a default option designated by the employer unless the employee chooses an alternative. Default options are commonly index funds or target date funds that include one or more index funds.

In addition, employee-investors are distinctive. Recent empirical research suggests that people who invest exclusively through 401(k) plans have very low levels of financial literacy - lower in fact than other investors. ${ }^{103}$ One

\footnotetext{
${ }^{100}$ ICI Fact Book 2019 at 136. 142

${ }^{101} \mathrm{Id}$. at 142.

${ }^{102}$ See, e.g., Bob Pisani, 'America's retirement accounts are growing, but not fast enough' (2018) CNBC https://www.cnbc.com/2019/06/12/americas-retirementaccounts-are-growing-but-not-fast-enough.html (reporting that "At year-end 2018, $48 \%$ of Vanguard plans had adopted automatic enrollment and $66 \%$ of new plan entrants were signed up that way.").

${ }^{103}$ See Jill Fisch, Annamaria Lusardi \& Andrea Hasler 'Defined Contribution Plans and the Challenge of Financial Illiteracy (forthcoming 2019) Cornell Law
} 
study reports that "only slightly more than one third (37 percent) of workplaceonly investors have some basic financial knowledge as measured by the Big Three, and only 35 percent can answer the question about compound interest correctly." 104

Concededly setting priorities with respect to stewardship and ESG involves different skill sets than financial literacy. Even if investors do not understand compound interest, they can identify and express their preferences with respect to policy issues like corporate political spending, executive compensation and climate change. The problem is that, even if investors' general policy positions is clear, understanding the business ramifications of those positions with respect to a particular portfolio company is quite complex. ${ }^{105}$

Moreover, extrapolating from investors' general policy positions into a workable set of voting guidelines is more difficult than it initially appears. Media reports highlight this challenge when they criticize mutual funds for their voting records. ${ }^{106}$ For example, corporations face an increasing number and range of ESG-related shareholder proposals, particularly proposals seeking reporting or the adoption of formal board policies with respect to various social policy concerns, ${ }^{107}$ but there are reasons why a shareholder who supports diversity may not support a particular diversity proposal. ${ }^{108}$ Similarly a shareholder who opposes food waste or is concerned about climate change might nonetheless decide that requiring an issuer report publicly on such issues is not cost-justified. If it is difficult even to figure out what a rational shareholder

Review (reporting that levels of financial literacy among workplace-only investors were "strikingly low.").

${ }^{104} \mathrm{Id}$.

${ }^{105}$ A recent Wall Street Journal article highlights the impact of the "stakeholder model" on PG\&E. Allysia Finley, "Stakeholder" Capitalism in Action' (21 Oct. 2019) Wall St. J. https://www.wsj.com/articles/stakeholder-capitalism-in-action11571696787

${ }^{106}$ See, e.g., Braham, supra note

${ }^{107}$ Shareholders at Amazon's $201 \overline{9}$ annual meeting, for example, introduced resolutions seeking the company to disclose "the environmental and social impacts of food waste generated from the company's operations" and to "report on its efforts to address hate speech and the sale of offensive products throughout its businesses".

${ }^{108}$ Consider, for example, the Amazon shareholder proposal on "board diversity." (calling the Board to implement a "Rooney Rule" with the "true diversity" proposal introduced by some conservative groups calling for greater ideological diversity on corporate boards) Kevin Mooney, 'Conservative Shareholders Push Facebook to Achieve "True Diversity"' (29 May 2019) The Daily Signal https://www.dailysignal.com/2019/05/29/conservative-shareholders-pushfacebook-to-achieve-true-diversity/ 
would prefer, it is hard to see how the average mutual fund investor could develop meaningful policy positions, especially when the impact of his or her preferences on the policies of the underlying portfolio companies is likely to be quite small.

A more practical concern with pass-through voting is voter turnout. ${ }^{109}$ Ordinary retail investors typically vote less than $30 \%$ of their shares in corporate elections. Voting participation by retail stockholders in mutual funds is even lower, and mutual funds have consistently experienced difficulty in obtaining a quorum in their shareholder meetings, even though a quorum may require as few as one third of the outstanding shares of the fund. ${ }^{110}$ Low voter turnout is more common among shareholders in passive funds, who tend to "set it and forget it." 111 Moreover, because any given mutual fund generally holds hundreds of portfolio companies or more, the number of occasions on which mutual fund shareholders will be called upon to vote is substantially greater than for ordinary retail investors.

Of course, limited participation need not prevent a mutual fund from following the preferences of those beneficiaries who participate actively. Because participation is likely to be higher by wealthier investors, however, this

\footnotetext{
${ }^{109}$ Paul Schott Stevens, 'SEC Should Reject Complex, Costly "Pass-Through" Proxy Voting' (2018)

https://www.ici.org/viewpoints/view_18_passthrough_voting?WT.mc_id=view_18 passthrough_voting\&WT.sn type $=$ FACEBOOKPAGE\&hoot.message $=$ The $\% 20 \mathrm{~S}$ EC\%20should $\% 20$ reject $\% 20$ complex $\% 2 \mathrm{C} \% 20$ costly $\% 20 \% \mathrm{E} 2 \% 80 \% 9$ Cpassthrough\%E2\%80\%9D\%20proxy\%20voting $\%$ E2\%80\%94the \%20idea $\% 20$ of $\% 20$ fo rcing $\% 20$ funds $\% 20$ to $\% 20$ poll $\% 20$ their $\% 20$ shareholders $\% 20$ before $\% 20$ voting $\% 20$ company $\% 20$ proxies $\%$ E2\%80\%94says $\% 20 \mathrm{ICI} \% 20$ President $\% 20$ and $\% 20$ CEO $\% 2$ 0Paul $\% 20$ Schott $\% 20$ Stevens $\% 3 \mathrm{~A} \% 20 \% 5 \mathrm{BLINK} \% 5 \mathrm{D} \&$ hoot.send date $=2018-10$ 02\%2020\%3A02\%3A54\&hoot.username=Investment $\% 20$ Company $\% 20$ Institute\& hoot.send dayofweek=Tuesday\&hoot.send_hour $=20$. Notably, although some commentators such as Lund argue that low turnout is unproblematic if it reduces the instances of uninformed voting, if particular groups of shareholders are systematically underrepresented, it is problematic to view voting results as indicative of shareholder preferences. Lund, supra note .

${ }^{110}$ Ross Kerber 'Vanguard asks passive investors to pay attention for proxy vote' (19 Sept. 2017) Reuters https://www.reuters.com/article/us-vanguardinvestors/vanguard-asks-passive-investors-to-pay-attention-for-proxy-voteidUSKCN1BU2G9 See also Statement of Paul Schott Stevens, President and CEO Investment Company Institute, U.S. Securities and Exchange Commission Proxy Voting Roundtable "Broker Proxy Voting" (2007) https://www.sec.gov/comments/4-537/4537-32.pdf (observing that, in sample of mutual fund annual meetings involving a non-routine matter, half required a resolicitation because of the failure to obtain quorum).

${ }^{111}$ Kerber, supra note 110 .
} 
approach cuts against the democratic claims of some pass-through voting advocates. There are also reasons to question whether the preferences of wealthy retail shareholders with respect to particular policy issues or more generally regarding the trade-off between corporate profit and non-economic values mirror those of less sophisticated workplace-only investors.

Perhaps the most problematic concern about pass-through voting, however, is that, to the extent a mutual fund adviser votes in accordance with the preferences of its beneficiaries, it loses its power to negotiate with issuers for change. ${ }^{112}$ A key rationale for increased investor stewardship is the prospect that, because of their size and voting power, institutional investors have the ability to influence the behavior of their portfolio companies. Indeed, this influence can be observed not merely through voting outcomes but by noting the number of shareholder resolutions that result in negotiated withdrawals following management's acquiescence or commitment to voluntary action. ${ }^{113}$ An institutional investor that relinquishes control over its voting decisions sacrifices a powerful component of its ability to engage successfully.

\section{CONCLUSION}

Investor stewardship is a potentially powerful tool for influencing corporate behavior. As a result, it should be handled with care. Because index funds own an increasing percentage of global equity, they face growing scrutiny about their stewardship role, and a number of commentators have demanded that they do more to influence the decisions made at their portfolio companies. This chapter argues for caution in making such demands. Index funds offer their investors broad diversification at low cost, a model that is in tension with demands for high quality firm-specific engagement. Further, to the extent that stewardship encompasses pursuit of broad societal goals or balancing economic and non-economic objectives, index funds lack the tools to do so in a way that is faithful to the interests of their beneficiaries. Although these concerns could

112 See Edward Rock \& Marcel Kahan, 'Index Funds and Corporate Governance: Let Shareholders be Shareholders' (2019)

https://papers.ssrn.com/sol3/papers.cfm?abstract $\mathrm{id}=3295098$ (ascribing the ability of asset managers to influence portfolio company behavior to the heft associated with their voting power).

${ }^{113}$ See, e.g., Paul Rissman \& Diana Kearney 'Rise of the Shadow ESG Regulators: Investment Advisers, Sustainability Accounting, and Their Effects on Corporate Social Responsibility' (2019) 49 ELR 10171, https://www.eli.org/sites/default/files/elr/featuredarticles/49.10155.pdf (reporting that $45 \%$ of shareholder proposals requesting a sustainability report "were withdrawn by the filer following an engagement with management that produced a commitment to publish, and therefore never came to a vote.") 
be addressed by giving index fund shareholders greater voice, it is not clear that such reforms would be efficient or cost-effective. 